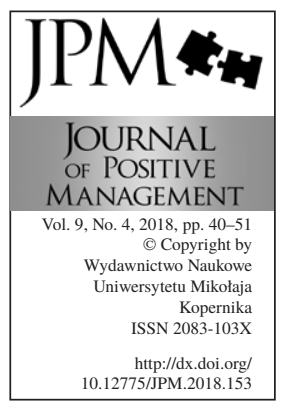

\title{
COMPETENCE REQUIREMENTS AS \\ A CHALLENGE OF MODERN JOB \\ MARKET - EXAMPLE OF REGIONAL \\ RESEARCH ON HUMAN CAPITAL
}

\author{
Joanna Lajstet \\ Nicolaus Copernicus University in Torun, Torun, Poland \\ e-mail: joanna.lajstet@gmail.com
}

\begin{abstract}
The main aim of this article is to shows a sample of conclusions based on conducted research that show what the biggest deficits in the area of human capital there are these days. Increasing the quality of human capital is a challenge not only for companies but also for the regional development. Investing in its quality must be made within the framework of strategies based on thorough diagnosis and real needs. The article refers to the examples of conducted research on Kuyavian-Pomeranian job market and it being used while designing public intervention in the area of investment in human capital. It also shows the findings of research conducted within the years 2008-2014 (altogether 10 thousand employers were interviewed in the whole region) that reveal competence mismatching, which can be a barrier for the development to not only regional economy but also to the development of particular companies.
\end{abstract}

Keywords: demand for qualifications, development of human resources, human capital

Paper type: Research paper

\section{Introduction}

Observation of changes on the job market and providing knowledge about mechanisms and processes going there are essential elements that influence the development of entrepreneurship, economic efficiency of not only companies and economy sectors but also some areas. Expectations for employees' qualifications are the subject of constant interest of job market's observers, including public employment services and human capital and development of human resources are the key supply for companies and organizations. Knowledge, education and employees' qualifications that make it possible for them to do their job and achieve set social aims (what we regard as human capital in its narrow definition) are more and more important both in reference 
to company's management as well as public policies. Human capital is defined contemporarily by for example OECD as "knowledge, abilities, skills and other qualities of a human being which are essential to economic activity" (OECD, 1998) or "knowledge, abilities, skills and other qualities of a human being which make it possible to generate personal, social and economic welfare" (OECD, 2001). Human capital is understood as a resource of knowledge and abilities of a human being as well as community and it can be increased through investments in education (trainings and professional development during work time, education in the area of national education) [1]. Changes on the job market - for example transforming the conditions of work cause that the matter of lifelong learning is a challenge which all the actors must face. The phenomenon is a problem for people looking for a job and public politics for example when creating strategies for fighting unemployment as well as for the development of companies that have to face the challenge at the stage of formulating the strategy of development of company's human resources.

Despite the fact that the nowadays labour market oftentimes evade longterm predictions, the research on the demand for qualifications and for certain occupations and the changes to the said demands is both a vital element for determining the current state of affairs and a departure point for predicting future demands. The necessity of the research on currently sought-after occupations stems from - among others - the need to provide the knowledge needed to determine the ill-adjustments of the occupations on the labour market as well as to diagnose the lacking competences. The information provided by employers are the key source in this realm.

The aim of the paper is first and foremost the presentation of the issues related to the methodology of the research conducted in 2008-2014 on employers in the Kujawsko-Pomorskie Voivodeship. Presenting the selected practical aspects of research studies as well as collecting and processing data makes some room for reflections upon the strategies of taking decisions and of public interventions, especially with respect to adjusting qualification to the demands of labour market. The research conducted by Voivodeship Labour Office [hereinafter referred to as WUP] in Torun and the analysis of labour market provided the information which is useful for determining the tendencies in the local labour market and the very information was exploited to predict and plan - among others - the education policy as well as the actions related to occupational activation of the selected groups. Basing one's decision as to the realized tasks on the obtained data was to warrant the adjustment of action to real demands (WUP, 2013c).

The analyses and the results of the single-handedly conducted research constituted the primary sources of information about the regional labour market. Through the said research, what was made possible was the creation of public intervention based on facts (evidence-based policy). 
COMPETENCE REQUIREMENTS AS A CHALLENGE

Joanna Lajstet
On the other hand the article shows a sample of conclusions based on conducted research that show what the biggest deficits in the area of human capital there are these days. It portrays the changes of modern job market and the organizations working there for which the issue of mismatching the competences is one of the vital matters as well as the source of problems focusing the interest of all the actors of job market.

The information adduced in this paper comes from the publicly available sources related to the research conducted in 2008-2014, in particular from: postresearch reports (WUP, 2008, 2009, 2010a, 2012a, 2012b, 2013a, 2013b, 2015b), two publications recapitulating the systemic projects realized by WUP in Torun [see: WUP, 2013c, 2015a] and methodological materials available at the internet site of WUP in Torun, at the site of the systemic project of WUP in Torun bearing the title „Rynek pracy pod lupą” [Labour Market under the spotlight] as well as in the database of research projects EFS (WUP, 2010b, 2011a, 2011b).

\section{The sources for acquiring data on the demand for competences on the regional labour market}

The duty to analyze data incumbent upon the public employment services, including voivodeship labour offices, are regulated by the Employment Promotion and Labour Market Institutions Act. The duties of the voivodeship's self-government within the labour market policy in the period under scrutiny embraces - among other - what follows: investigating the demand for labour, including monitoring undersupplied and oversupplied professions [the Act of 20 April, 2004]. The task of public employment services is to provide among others - the information serving to adjust the educational profiles and professional trainings for the unemployed to the demands of the labour market. The challenges that labour offices have to face, the challenges related to the data-analyzing activities being - among others - the question of the way of realizing research and the issue of the availability of the sources of the data. What the realm of the activities related to the data-analyzing by public services encompasses is the statistical analyses of data pertaining to the unemployed in the voivodeship, the already existent research and analyses realized by other institutions and the realization of social research (single-handedly as well as when commissioned by some external entities). The genesis of the realization of the research on the employers originated from the troubling situation on the labour market in the Kujawsko-Pomorskie Voivodeship and from the lack of reliable data indispensable for taking efficient actions for the sake of increasing the employment rate in the said regions as well as regional development, including investment in human capital (WUP, 2010b, 2013c).

The knowledge on the competences sought after on the labour market in the years referred to in the paper was available only to a small extent in the 
external data published by Główny Urząd Statystyczny [Central Statistical Office, hereinafter referred to as GUS], presenting the results of the research conducted in our country and related to the demand for labour [2].

As we can read in the introduction of the report of the research realized in 2008: "the foundation for the successful provision of the services for the sake of the unemployed is the exploitation of the knowledge on the present state of the demand for labour in a given powiat".

The effective system of information about the demand on the labour market should take into account the employment plans by the employers in a specific field. The information about the demand for labour which were at our disposal (the data at GUS' disposal) did not allow for diagnosing the situation in a given powiat and neither did they demonstrate the specifics of the local labour market, nor its demands, in particular qualifications of the future employees desired and sought after by the employers. The research conducted by GUS provided the information related to the unoccupied and newly-created vacancies; yet, it did not address the issue of downsizing. With reference to the above, at the onset of 2008, the methodology of the pilot research on the employers of the Kujawsko-Pomorskie Voivodeship was laid out. The main purpose of the said research was to diagnose the employment plans at the workplaces on the territory of particular powiats of the voivodeship" (WUP, 2008).

During the realization of the research scrutinizing the employers of the Kujawsko-Pomorskie Voivodeship, there simultaneously commenced the research conducted by Polska Agencja Rozwoju Przedsiębiorczości [Polish Agency for Enterprise Development] as a part of the project Bilans Kapitału Ludzkiego [The Balance Sheet of Human Capital]. The data collected in this project is a source of information on the demands of employers, the data thus serving as a benchmark against which one could evaluate the validity of the research realized by the public employment services in the Kujawsko-Pomorskie Voivodeship. The possibility of referring the findings to others of a similar scope and subject has shown two very important questions. The first one is that the knowledge that was gained during the research "Demand for Job" and "Monitoring of deficit and surplus occupations" did not embrace the information about wanted personal traits, they were totally insensitive to those factors that turned out to be really vital from the point of view of employers' needs and the challenges of modern job market that I mentioned in the introduction. The second conclusion resulting from the possibility of referring the results of the research of employers conducted by Public Employment Services in Kuyavian-Pomeranian region to the findings of Balance of Human Capital conducted by Polish Agency of Entrepreneurship Development (PARP) was that the significance of personal traits, possessing appropriate competences as well as willingness to work in many sectors of job market is essential. Before I quote the findings that refer to the needs and conclusions of the research I will discuss
COMPETENCE REQUIREMENTS AS A CHALLENGE

Joanna Lajstet 
COMPETENCE REQUIREMENTS AS A CHALLENGE

Joanna Lajstet

Table 1. Sample size in the research on the employers in the KujawskoPomorskie Voivodeship in 2008-2014

Source: my own study on the basis on the reports about the research on employers in the Kujawsko-Pomorskie Voivodeship (WUP, 2008, 2009, 2010, 2012a, 2012b, 2013a, 2013b, 2015) the methodology of surveying the employers in Kuyavian-Pomeranian region and examples of its usage.

\section{The research on the demand for qualifications in the Kujawsko- Pomorskie Voivodeship}

\subsection{The assumptions and the procedure of realizing the research on the employers [3]}

WUP in Torun, since 2008, has been conducting once a year among the employers in this very voivodeship the research the aim of which was to find out the demand for qualifications among the surveyed employers. The research was realized by WUP in Torun in cooperation with all the provincial labour offices in the voivodeship. Through the research, the investigators planned identify the key employers in the region, the latter meaning the ones employing the greatest number of people. These employers were supposed to be able to indicate the professions to which their potential employees would belong to. Furthermore, they were supposed to specify the most desirable abilities in their candidates for employees. The assumption underpinning the research from the very beginning was surveying those employers who were regarded as vital in the region. Altogether, within 8 successive editions of the research, it was about 10 thousand employers that were subjects to the research. The survey had the nature of direct survey. The technique employed in the research was questionnaires. The data collection instrument was the very questionnaire of the survey.

\begin{tabular}{lllllllll}
\hline & \multicolumn{7}{c}{$\begin{array}{l}\text { Sample size in the research on employers in the Ku- } \\
\text { jawsko-Pomorskie Voivodeship in 2008-2014 }\end{array}$} \\
\cline { 2 - 8 } Itemization & \multicolumn{7}{c}{ Year of research } \\
\cline { 2 - 8 } & $\mathbf{2 0 0 8}$ & $\mathbf{2 0 0 9}$ & $\mathbf{2 0 1 0}$ & $\mathbf{2 0 1 1}$ & $\mathbf{2 0 1 2}$ & $\mathbf{2 0 1 3}$ & $\mathbf{2 0 1 4}$ \\
\hline $\begin{array}{l}\text { The total number of realized } \\
\text { questionnaires }\end{array}$ & 688 & 1132 & 2054 & 2049 & 2031 & 1873 & 445 \\
\hline
\end{tabular}

What was subject to research were business entities from the entire KujawskoPomorskie Voivodeship. The principle of selection was the three-fold division according to the size of employment.

- Business entities employing no less than 50 people - the entities of this group were to constitute $50 \%$ of the entire sample, that is they amounted to about 1000 entities.

- Business entities employing from 10 to 49 people - the entities of this group constituted about $25 \%$ of the entire sample, that is there were as many as 500 of them. 
- Business entities employing no more than 9 people - they were to constitute about $25 \%$ of the sample, that is about 1000 entities.

Sampling the entities from the group 50+ of people employed was realized by WUP on the basis of the database of REGON. The entities from the remaining groups were randomly selected by Urząd Statystyczny w Bydgoszczy [Statistical Office in Bydgoszcz] on the basis of the commission submitted by WUP in Torun. The research conducted in 2014, the issue of the predicted demand for labour focues on the thematic approach; sample size was reduced and restricted to 6 branches specified in the strategic documents as the branches contributing to the development of the region (WUP, 2015a).

\subsection{The ways of making use of data}

The information collected during the research were made use of in the operations by WUP but it was also published and transferred to the institutions having a bearing on the labour market in the region. The goal pursued by the realizers of the research was that the said research should come in handy to the employers and the people looking after a job (WUP, 2010b, 2013c). The instantiations of the research on the demand for qualifications in the Kujawsko-Pomorskie Voivodeship serves as an illustration of how to realize the need for the adjusting the actions to the real need, the latter being the basis of the evidence-based policy. In the publication , Rynek pracy pod lupq” - podsumowanie realizacji projektu, prepared by Wydział Badań i Analysis [The Department of Research and Analysis of WUP in Toruń] we can see the instances of making use of the data collected from the - among others - research on employers.

One of them was the preparation of local information related to occupations by Centrum Informacji i Planowania Kariery Zawodowej WUP in Toruń [Centre of Information and Job Orientation]. The descriptions of the occupations were prepared - among others - on the basis of the data collected due to monitoring undersupplied and oversupplied occupations, as well on the basis of the research on employers and the analysis of the training market. The local information about the occupations served as the basis for issuing a verdict by Wojewódzka Rada Zatrudnienia [Voivodeship Employment Council] in the issues related to the directions of education, occupation trainings in the voivodeship, for example, on the basis of the information about the occupations, what was enacted was the act of Zarząd Województwa [The Board of the Voivodeship] related to the size of student enrolment to the schools subject to the self-government of the voivodeship in the school year 2012/2013 (WUP, 2013c).

The information about the occupations was a constituent of the cooperation established with schools and universities. The said cooperation encompassed meetings with the representatives of academic career offices of the universities from the voivodeship. It also embraced the descriptions of the state of affairs in 
COMPETENCE REQUIREMENTS AS A CHALLENGE

Joanna Lajstet the occupations calling for higher education on the labour market. Eventually, it also included the description of the activities for youth and adults, the activities being related to the situation on the labour market in given occupations requiring post-gimnazjum education (WUP, 2013c).

Surveys on the employers, being an element of the system for diagnosing the demand for labour and qualifications within the regional labor market, constituted a great source of knowledge exploited at the stage of preparing the realization of Podziałanie 6.1.1 PO KL [Submeasure 6.1.1. Human Capital Operational Programme] [8] - among others - Plany Działań dla Priorytetu VI PO KL [Action Plans for the Priority VI POKL]. Next, the results of the realized research were referred to during the evaluation of the projects.

Each time, the results of the realized research served as the basis for working out the report with the diagnosis for the Kujawsko-Pomorskie Voivodeship as well as the basis for the tables presenting the collected information in details.

Above, there were indicated the selected examples which could illustrate the rule of adjusting the actions to the real needs. The level of data aggregation stemming from the research on the employers, the research being realized by WUP in Torun, makes the data such that the way of collecting and processing thereof opened the possibility of its wide application. It was the case because the data was presented in reference to particular occupations (in accordance with the operative classifications of occupations and specializations), powiats - by dint of Polska Klasyfikacja Działalności [Polish Classification of Activities]. The data also took into account the detailed expectations by employers towards various competences of employees. The data was collected systematically with the use of similar questionnaires in which the constant elements of diagnosing can be indicated. It enabled the transformation of the part of the data into panel research and thus the chance emerged for the verification of the information obtained from the employers and hence, it increased their credibility. The realization of the research allowed for making comparisons not only across years but also using the criterion of particular occupations and sections, while the year could be kept constant (WUP, 2008, 2009, 2010a, 2012a, 2012b, 2013a, 2013b, 2015b).

It is worthwhile to also pay attention to the fact that the diagnosis of the changes planned in the realm of employment, downsizing inclusive and taking into consideration the occupation held by the persons subject to the predicted dismissals, provided valuable information for public employment services in the context of the planned active labour market policy. On the nowadays labour market, flexibly reacting to the ever-fluctuating demands is a challenge of fundamental significance both for the actions of public employment services and for the education system. 
4. Competence requirements or about challenges employers of job market face

Main aim of the research discussed in the article was to diagnose the demands of employees in particular occupations as well as define what qualifications and competences candidates for the job should have.

The conclusions from surveying the employers in Kuyavian-Pomeranian region showed that the wanted ones are mostly industrial workers and craftsmen, workers with simple work, service workers and shop assistants. Within all the editions of the research a great majority of job vacancies was in the three discussed groups of jobs. Quite often also once could notice a demand for operators and fitters of machines and devices. More than half of offered jobs was connected with vocational education. On the basis of survey of employers in KuyavianPomeranian region it can be stated that there is a huge demand for relatively low qualified employees. However, what was particularly visible in all the editions of conducted research was that many job candidates were more often expected to possess particular soft competences rather than job experience or education by their workers. Most often were expected :neatness of a job (78,3\% of all offered vacancies), team work ability $(71,9 \%)$, sense of duty $(66,2 \%)$ good organization of work $(64,7 \%)$ (WUP, 2013a). Soft competences were highly valued by employees, for example in 2010 the most desired individual qualities in new employees were: sense of duty, neatness and team work ability (WUP, 2010). The key resources of job candidates were good organization of work and interpersonal skills.

Agata Szydlik-Leszczyńska when describing the conditions for creation and development of modern organizations and current expectations of employers towards employees remarks that what is at present typical for companies that base their development on management of knowledge and gaining intellectual capital including human capital. In her opinion evolution of organizational models, technological changes lead to the change in the area of all jobs; Employees are expected to show bigger involvement and solve more and more complex problems and flattening the organizational structures and establishing network structures 'shifts down' competences and responsibility (Szydlik-Leszczyńska, 2012). In the light of the research conducted in Kujawsko-Pomorskie Voivodeship the conclusions seem to be really adequate. The changes observed in connection with the development of economy based on knowledge generate expectations in the field of competences, not only for specialists but also not highly qualified employees.

Similar conclusions can be found in the results of Human Capital Research. "Employers asked to point out the most needed competences job candidates on a given position, regardless of a job which they were looking for were required pointed out three categories of competences: self-organizational (time management, sometimes independence, taking decisions and showing initiative, 
COMPETENCE REQUIREMENTS AS A CHALLENGE

Joanna Lajstet stress resistance and willingness to work), professional (strictly connected with the responsibilities of a given position) and interpersonal ones (ability to contact people, to be communicative, to cooperate within a group as well as solve interpersonal conflicts). Other abilities were mentioned less often, which shows how common and at the same time essential are the three categories of competences and that candidates to work in any job have their deficits" (compare PARP, 2015).

PARP research provided us with one more conclusion, namely, among employers who conducted recruitment the difficulties with finding the right people for the jobs were common- three fourths of them stated that. Bigger problems with finding the employees had employers from smaller companies (compare PARP, 2015, s. 17). These conclusions show that entrepreneurs from SME sector will have particularly severe problems with finding appropriate people to work.

In opinion of the employers taking part in the research within the years 20102014 problems with finding appropriate people to work mostly results from the fact that the candidates themselves lack them - that they did not come up to the expectations connected with working on a given position. Apart from lack of appropriate competences and experience they often pointed out lack of motivation to work. Significant recruitment difficulties reported by employers did not result from existing shortage of employees in the most wanted occupations. Shortage of people applying for jobs in different occupations was seldom mentioned by employers. Most often they complained about their lack in candidates - lack of appropriate competences, experience and willingness to work (PARP, 2015)

\section{Summary}

Because of dynamic technological, organizational or cultural changes development of competences, their advancement in adulthood is not an option any more, it is becoming a necessity. The reflection and deliberation over the social practice meeting the requirement of adjusting actions to real demands is given priority in the debate on narrowing the competence gap on the labour market. The debate acquires the special significance only within the context of the challenges for the economy based on knowledge, of globalization processes, international migration, the observable demographic changes and of the necessities for educating oneself throughout one's life. These elements are decisive when it comes to the fact that reacting to the ever-changing demands on the labour market poses a challenge not only to public employment services or for education system but also for individually taken education- and occupation-related decisions. Another thing are recruitment problems experienced by employers connected with mismatching the competences and lack of expected personal qualities such as time management, independence, taking decision and showing initiative. It is connected with the fact 
that such competences are hard to develop during the process of education. In this context employers all the time play the essential role.

Conducting analyses of the regional labour market, the demand for employees and qualifications from the perspective of a particular voivodeship or powiat inclusive, is most of all a pursuit of a proper benchmark which would allow to diagnose the local labour market while simultaneously paying attention to the specifics of the region and not losing track of the wider reference to the generic expectations of globalized economy. The example of the research having been realized in the Kujawsko-Pomorskie Voivodeship reveals how broad and varied area of interest we deal with. It is visible not only in the variety of ways of making use of the data but also in the fact how many potential groups are the target of the actions taken; for example, youth, the unemployed and the employed. The information collected in the research was the valuable source of information; however, it gained in importance due to the possibility of carrying out comparative studies (repeatability of the research was its main asset) across the specified indicators but also in relations to external data. The findings of regional research conducted in Kuyavian-Pomeranian region in 2008-2014 as well as conducted within the project Balance of Human Capital in 2010-2014 make it possible to point out the most important directions and challenges for creating the strategies of investment in human capital both within for example regional policy of job market as well as the development of human resources in companies. The diagnosis of desired, competences, abilities or more widely human capital on the job market will call for bigger involvement on the side of employers and more emphasis put on the issues connected with company management and looking for efficient ways of dealing with challenges such as recruitment, attracting talents or keeping key workers. Facing difficulties with finding appropriate employees does not result from shortage of workers in desired jobs but just lack of appropriate competences or willingness to work (compare PARP, 2015). For modern organizations where people are the resource of special importance the possibilities of development depend on the way the company copes with the need to adapt to the challenges. The challenges are equally important when managing the company as well as in public policy for which the matter of influence of human capital on local development is equally essential.

\section{Notes}

[1] http://encyklopedia.pwn.pl/haslo/kapital-ludzki;3920045.html (accessed 26 April 2017).

[2] See: http://stat.gov.pl/obszary-tematyczne/rynek-pracy/popyt-na-prace/ (accessed 26 August 2016).

[3] The study on the basis of the materials presenting the methodology of the research conducted:

a) The methodology of the research „Sondaż pracodawców województwa kujawsko-pomorskiego. Diagnoza zapotrzebowania na pracowników w wymiarze kwalifikacyjno-zawodowym”, available 
COMPETENCE REQUIREMENTS AS A CHALLENGE

Joanna Lajstet at: https://pokl.wup.torun.pl/images/stories/projekty_systemowe_wup/wyniki_badania_pracodawcow/2.pdf (accessed 26 August 2016);

b) Methodology of the research on employers on the local labour market. The research conducted by the labour offices in the voivodeship of Kuyavia and Pomerania, http://podlupa.wup.torun.pl/ wp-content/uploads/2012/03/metodologia_czerwiec_2011-wyd-2-2.pdf (accessed 26 August 2016), as well as the publications recapitulating the realized systemic projects served as the source for the below-stated reconstruction of the procedure of research-conducting.

[4] The information about the realized systemic projects is available at: https://pokl.wup.torun.pl/ index.php?option=com_content\&view=article\&id=107\&Itemid=122 (accessed 26 August 2016).

[5] https://pokl.wup.torun.pl/images/stories/projekty_systemowe_wup/pmrrp_01.06.2009r.pdf (accessed 26 August 2016).

[6] The instances thereof are the meeting with the powiat labour officer who were responsible for (during the conduct of the research) for surveying the subjects to the research.

[7] https://pokl.wup.torun.pl/images/stories/projekty_systemowe/kwestionariusz.htm, http://podlupa.wup.torun.pl/biblioteka/raporty-wyniki/\#pracodawcy_kot (accessed 26 August 2016).

[8] Within the competition of Poddziałanie 6.1.1. on the basis of - among others - the results of the research on the employers the strategic criterion was employed, the criterion promoting the projects assuming that as a result of the implementation of the trainings at least $50 \%$ of the project members should obtain the qualifications in the occupations sought after on the labour market in the voivodeship of Kuyavia and Pomerania [see: WUP, 2013c, p. 43].

\section{References}

OECD (1998), "The knowledge, skills, competences and other attributes embodied in individuals that are relevant to economic activity", Human Capital Investment, An international Comparison. OECD Publishing, available at: http://www.oecd-ilibrary. org/education/human-capital-investment_9789264162891-en (accessed 26 April 2017).

OECD (2001), "The knowledge, skills, competencies and attributes embodied in individuals that facilitate the creation of personal, social and economic well-being.", The Well-being of Nations, The Role of Human and Social Capital. Publishing, available at: http://www.oecd.org/site/worldforum/33703702.pdf (accessed 26 April 2017).

Szydlik-Leszczyńska, A. (2012), Funkcjonowanie współczesnego rynku pracy. Wybrane uwarunkowania, Difin, Warszawa.

Ustawa z dnia 20 kwietnia 2004 r. o promocji zatrudnienia i instytucjach rynku pracy (Dz. U. Nr 99 poz. 1001 ze zm.).

Wojewódzki Urząd Pracy w Toruniu (2008), „Sondaż wśród pracodawców województwa kujawsko-pomorskiego", available at: http://wup.torun.pl/urzad/publikacje/ publikacje-dotyczace-rynku-pracy/ (accessed 26 April 2017).

Wojewódzki Urząd Pracy w Toruniu (2009), ,Sondaż wśród pracodawców województwa kujawsko-pomorskiego 2009 r.", available at: http://wup.torun.pl/urzad/publikacje/ publikacje-dotyczace-rynku-pracy/ (accessed 26 April 2017).

Wojewódzki Urząd Pracy w Toruniu (2010a), „Sondaż pracodawców województwa kujawsko-pomorskiego - diagnoza zapotrzebowania na pracowników w wymiarze kwalifikacyjno-zawodowym", available at: http://wup.torun.pl/urzad/publikacje/ publikacje-dotyczace-rynku-pracy/ (accessed 26 April 2017). 
Wojewódzki Urząd Pracy w Toruniu (2010b), „Metodologia badania pracodawców na lokalnym rynku pracy Badanie realizowane przez urzędy pracy w województwie kujawsko-pomorskim", available at: https://www.efs.2007-2013.gov.pl/ analizyraportypodsumowania/baza_projektow_badawczych_efs/documents/metodologia_badania_pracodawcow_na_lokalnym_rynku_pracy_torun.pdf (accessed 26 August 2016).

Wojewódzki Urząd Pracy w Toruniu (2011a), „Metodologia badania «Sondaż pracodawców województwa kujawsko-pomorskiego. Diagnoza zapotrzebowania na pracowników w wymiarze kwalifikacyjno-zawodowym»”, available at: https://pokl. wup.torun.pl/images/stories/projekty_systemowe_wup/wyniki_badania_pracodawcow/2.pdf (accessed 26 April 2017).

Wojewódzki Urząd Pracy w Toruniu (2011b), „Metodologia badania pracodawców na lokalnym rynku pracy. Badanie realizowane przez urzędy pracy w województwie kujawskopomorskim", available at: http://podlupa.wup.torun.pl/wp-content/ uploads/2012/03/metodologia_czerwiec_2011-wyd-2-2.pdf (accessed 26 April 2017).

Wojewódzki Urząd Pracy w Toruniu (2012a), „Sondaż pracodawców województwa kujawsko-pomorskiego - diagnoza zapotrzebowania na pracowników w wymiarze kwalifikacyjno-zawodowym", available at: http://wup.torun.pl/urzad/publikacje/ publikacje-dotyczace-rynku-pracy/ (accessed 26 April 2017).

Wojewódzki Urząd Pracy w Toruniu (2012b), „Badanie ankietowe pracodawców województwa kujawsko-pomorskiego w 2011 r.”, available at: http://wup.torun.pl/urzad/ publikacje/publikacje-dotyczace-rynku-pracy/ (accessed 26 April 2017).

Wojewódzki Urząd Pracy w Toruniu (2013a), „Badanie ankietowe pracodawców w województwie kujawsko-pomorskim w 2013 r.", available at: http://wup.torun.pl/ urzad/publikacje/publikacje-dotyczace-rynku-pracy/ (accessed 26 April 2017).

Wojewódzki Urząd Pracy w Toruniu (2013b), „Badanie ankietowe pracodawców województwa kujawsko-pomorskiego w 2012 roku", available at: http://wup.torun.pl/urzad/ publikacje/publikacje-dotyczace-rynku-pracy/ (accessed 26 April 2017).

Wojewódzki Urząd Pracy w Toruniu (2013c), ,Rynek pracy pod lupa - podsumowanie realizacji projektu", available at: http://podlupa.wup.torun.pl/biblioteka/raportywyniki/ (accessed 26 April 2017).

Wojewódzki Urząd Pracy w Toruniu (2015a), „Rynek pracy województwa kujawskopomorskiego w świetle badań prowadzonych przez Wojewódzki Urząd Pracy w Toruniu", available at: http://podlupa.wup.torun.pl/biblioteka/raporty-wyniki/ (accessed 26 April 2017).

Wojewódzki Urząd Pracy w Toruniu (2015b), „Badanie ankietowe pracodawców kluczowych branż województwa kujawsko-pomorskiego w 2014 r.”, available at: http:// wup.torun.pl/urzad/publikacje/publikacje-dotyczace-rynku-pracy/ (accessed 26 April 2017). 